\title{
Dimensions of the New Belt \& Road International Order: An Analysis of the Emerging Legal Norms and a Conceptionalisation of the Regulation of Disputes
}

\author{
Malik R. Dahlan \\ Centre for Commercial Law Studies (CCLS), Queen Mary University of London, London, UK \\ Email: m.dahlan@qmul.ac.uk
}

How to cite this paper: Dahlan, M. R. (2018). Dimensions of the New Belt \& Road International Order: An Analysis of the Emerging Legal Norms and a Conceptionalisation of the Regulation of Disputes. Beijing Law Review, 9, 87-112. https://doi.org/10.4236/blr.2018.91007

Received: February 27, 2018

Accepted: March 27, 2018

Published: March 30, 2018

Copyright $\odot 2018$ by author and Scientific Research Publishing Inc. This work is licensed under the Creative Commons Attribution International License (CC BY 4.0).

http://creativecommons.org/licenses/by/4.0/

(c) (i) Open Access

\begin{abstract}
China's "Belt \& Road" initiative ("BRI") has the potential to redefine international trade governance and the laws that establish its order. As a result, new international legal norms are emerging that are characteristically "Eastern". With a new international trade and investment order will come disputes over its interpretation. However, current dispute resolution mechanisms, including Investor State Dispute Settlement ("ISDS"), may not be efficient in resolving disagreements between the BRI's participating states, or investors therein. In order to overcome this practical challenge, this paper examines some important legal aspects of the BRI and offers a new concept of dispute regulation in general. As such, it firstly introduces the BRI as well as the Asian Infrastructure Investment Bank (AIIB), and explores their relationship. Secondly, it tackles selective legal aspects, norms and questions that are emerging as a result of the BRI. For the central argument, four traditional dispute resolution mechanisms are analyzed to inform a new BRI paradigm. This is supported by the special nature of the BRI, and the unique characteristics of countries participating in it. The paper is intended to begin a discussion of some emerging trends in international trade and the rules that relate to it, in the context of the BRI.
\end{abstract}

\section{Keywords}

Belt and Road Initiative/B\&R Initiative/BRI/OBOR, China, AIIB, Investment, Trade, Dispute Resolution Mechanism, Settlement, ISDS, Arbitration, Mediation 


\section{Introduction}

Since its promulgation by President Xi Jinping in 2013, the "Belt and Road" initiative" (which brings together the Silk Road Economic Belt and the $21^{\text {st }}$-Century Maritime Silk Road, also known as the "B\&R Initiative", the "BRI", the "Initiative" or "OBOR") has attracted attention both in China and abroad $^{1}$. For the moment, the initiative is an economic proposal whose implementation is in need of cultural integration and legal protection in participating countries. Among the sixty-five Participating States, some are common law countries (such as India and Pakistan), some are continental civil law countries (such as Mongolia and Burma), and most of the Middle East (excluding Iraq and Israel) belong to Islamic and hybrid legal systems. Due to differences in legal systems, cultures and environments, as well as unstable political and economic conditions, financial and trade disputes between parties cannot be avoided. As interesting example of instability in the political sphere, Robert Mugabe, the former president of Zimbabwe, resigned from office in 2017 after a coup that ended his thirty-seven year rule (Onishi \& Moyo, 2017). To cite an example of an unexpected economic development, the Hambantota deep-water port project, which was being advanced jointly by China and Sri Lanka, nearly collapsed following Sri Lanka's inability to repay a sizeable loan to China. The China Merchants Port Holdings Company Limited had to intervene to rescue the venture, obtaining in the process management rights over the project for ninety-nine years. This move prompted objections from both the local communities and among Sri Lankan politicians, which cast grave uncertainty over the project. Accordingly, three kinds of disputes could arise, namely: a) commercial dispute, b) an international trade dispute (between states), and c) an investment dispute (between an investor, usually foreign, and a host state) (Wang, 2017).

Generally, international commercial arbitration such as the dispute resolution mechanism of the World Trade Organization ("WTO"), and Investor State Dispute Settlement ("ISDS") ${ }^{2}$, are faced with the challenges of time-consuming processes, a lack of transparency, dangers to state sovereignty and high costs. Effective enforcement of arbitral awards is another obstacle relevant parties have to manage in practice ${ }^{3}$. Nevertheless, the added value of an ISDS is manifold. In the past, investors seeking to obtain remedies had to lobby their governments into negotiating the dispute on a state-to-state level. The establishment of ISDS has helped to avoid this politicization of conflicts, and the growth of foreign in-

${ }^{1}$ From 2013 to 2017, the attention of media and internet users both home and abroad to the BRI has risen at an average rate of around $20 \%$ annually. The US, India, the UK, Russia and Australia paid the closest attention to the BRI, with Italy, Thailand, Turkey and Pakistan close behind.

https://www.yidaiyilu.gov.cn/xwzx/gnxw/43662.htm accessed on 22 February 2018

${ }^{2}$ ISDS is a procedural mechanism provided for in international agreements on investment. ISDS allows an investor from one country to bring a case directly against the country in which they have invested before an arbitration tribunal. To bring a case, an investor must claim that the other Party has breached rules set out in the agreement.

http://trade.ec.europa.eu/doclib/docs/2013/october/tradoc_151791.pdf accessed on 12 March 2018

${ }^{3}$ Some countries along the Belt and Road are not contracting party of the New York Convention on the Recognition and Enforcement of Foreign Arbitral Awards. 
vestment has been helped by the establishment of ISDS as an adequate neutral dispute resolution system. When it comes to international trade disputes, the applicable rules of the WTO provide the compass in most cases. However, WTO rules cannot fully resolve disputes of the Participating States of the BRI, especially when many countries hosting BRI projects are not members of the $\mathrm{WTO}^{4}$. As for international commercial disputes, parties usually prefer arbitration over adjudicating in the domestic courts of a third country (Queen Mary, University of London and White \& Case, 2015).

In addition, among all the sixty-five Participating States of the BRI, more than fifty are contracting parties of the New York Convention on the Recognition and Enforcement of Foreign Arbitral Awards ("1958 New York Convention"), the prominent mechanism for the recognition and enforcement of a commercial arbitral award. However, fewer than 20 countries have signed civil or criminal judicial assistance treaties with China. When investment disputes arise as a result of infrastructure projects-a priority of the BRI-the political, economic and business landscape is usually both fluid and complex. Furthermore, in accordance with the World Investment Report 2017: Investment and the Digital Economy released by United Nations Conference on Trade and Development (UNCTAD, 2017), six out of the twelve most frequent respondent states between 1987 and 2016 are along the Belt and Road (the Czech Republic, thirty-four disputes; Egypt, twenty-eight; the Russian Federation, twenty-four; Poland, twenty-three; India and the Ukraine, twenty-one each). In many cases, softer measures and diplomatic means, such as negotiation and mediation, could be tried in the first place, taking into consideration eastern legal and cultural traditions. Nevertheless, a modified ISDS mechanism might still be the first and ultimate choice of relevant parties. This will be discussed in the later sections.

In most cases, ISDS provisions can be found in Bilateral Investment Treaties ("BITs") or free trade agreements ("FTAs"). To date, China has not signed any international investment agreements with twelve of the countries along the Belt and $\mathrm{Road}^{5}$. For all of the thirty-five BITs China has already signed with countries along the "Belt and Road", the ISDS provision is only applicable to disputes regarding particular amounts for expropriation compensation ${ }^{6}$. As a result, investor-state arbitration mechanisms are not applicable when the host country violates provisions of international investment agreements, such as obligations required by principles of fair and equitable treatment, national treatment and most-favored-nation treatment. In the past, China principally played the role of the host country. At present, however, a growing number of Chinese investors are shifting their focus towards overseas markets-especially against the background of the BRI.

\footnotetext{
${ }^{4}$ For example, Turkmenistan, Uzbekistan, Afghanistan, Azerbaijan, Bahrain, Iran, Iraq, Lebanon and Syria are not member states of the WTO.

${ }^{5}$ The twelve countries include East Timor, Bangladesh, Afghanistan, Nepal, Maldives, the Kingdom of Bhutan, Iraq, Jordan, Pakistan, Latvia, Bosnia and Herzegovina and the Republic of Montenegro. ${ }^{6}$ The thirty-five countries include some of the most important host countries for Chinese investors, such as the People's Republic of Mongolia, the United Arab Emirates, Turkey and Kazakhstan.
} 
A number of important academic contributions have proposed ways of improving the existing ISDS mechanisms. The first suggestion is to revise the way they are applied ${ }^{7}$, or introduce new bilateral and multilateral agreements ${ }^{8}$, or new forms of ISDS mechanisms. These mechanisms would include provisions that clearly define and distinguish between "Investor(s)" and "Investment(s)". Furthermore, additional national treatment provisions will be inserted, thus broadening the scope of investment arbitration and introducing bilateral appellate review systems (Huang, 2016). On the basis of the successful ASEAN-China Investment Agreement, an FTA might ultimately prove more efficient than new BITs, considering that the BRI concerns the rights and interests of numerous Participating States, covering a wide range of geographical areas. As will be examined elsewhere (Dahlan, forthcoming) the introduction of the concept of "the regulation of disputes", principally through mediation within ISDS, as a means to better regulate investor-state disputes could provide a swifter, more economic and more efficient way to improve the lifecycle of the dispute and compensate for procedural gaps in the current ISDS system. To that end, the idea of establishing a registry associated with BRI may indeed lead to the establishment of a much-needed global paradigm. This is supported by arguments made by scholars who advocate for the establishment of an ISDS center affiliated with the Asia Infrastructure Investment Bank (“AIIB”) (Han \& Zhai, 2017; Lu, 2017), comparable with the International Center for Settlement of Investment Disputes ("ICSID") under the International Bank for Reconstruction and Development ("World Bank"). Be that as it may, multilateral negotiations for a substantive regional or international infrastructure treaty are yet to commence. As such, the establishment of a dispute settlement mechanism with Asian characteristics aimed at circumventing substantive disputes could indeed provide a rejuvenating alternative to alternative dispute resolution ("ADR"). Parenthetically, the most comprehensive and representative of China's legal ethic characteristics might very well be the "Dispute Resolution Mechanism for the Belt and Road" ("Blue Book") put forth by the International Academy of the Belt and Road in October $2016^{9}$.

In order to support the pragmatic implementation of the BRI, the Blue Book is intended to apply to commercial, international trade and investment disputes. It features the introduction of a new set of rules covering ADR and arbitration. More importantly, it includes mediation as a pre-condition, along with conciliation and appeal procedures, a code of conduct and a set of transparency rules-a

${ }^{7}$ For example, India examined the BITs it had signed and published a new BIT template on 28 December 2015. This added a prepositive procedure for the exhaustion of local remedies, and also proposed the possibility of establishing an appellate institute.

${ }^{8} \mathrm{Up}$ to the present day, China has signed 145 bilateral investment agreements, among which 123 are in effect. Twenty-two BITs or FTAs include investment provision (and nineteen of these twenty-two agreements are in effect).

http://tfs.mofcom.gov.cn/article/Nocategory/201111/20111107819474.shtml http://investmentpolicyhub.unctad.org/IIA/CountryOtherIias/42\#iiaInnerMenu http://fta.mofcom.gov.cn/english/index.shtml accessed on 22 February 2018.

${ }^{9}$ http://interbeltandroad.org/en/ accessed on 22 February 2018. 
one-stop service. The less soft and perhaps more dated approach would be to resolve investor-state disputes through a judicial process by establishing a permanent court with an appeal mechanism. In December 2016, the European Commission proposed to establish a permanent multilateral investment court (consisting of a first-instance tribunal and an appeal tribunal) to decide investment disputes, moving away from ad hoc ISDS ${ }^{10,11}$. This may have been part of the Transatlantic Trade and Investment Partnership (“TTIP”), which was terminated after the election of Donald Trump ${ }^{12}$. Details of the tribunal can be seen in the agreed draft of the EU-Vietnam FTA of January $2016^{13}$.

\section{The Belt \& Road}

\subsection{The Background of the Initiative}

President Xi Jinping originally laid out the concept of BRI during his first visit to Central and Southeast Asia in 2013. On 28 March 2015, the National Development and Reform Commission ("NDRC"), the Ministry of Foreign Affairs, together with the Ministry of Commerce ("MOFCOM") published the "Vision and Action to Promote the Co-Construction of a 'Silk Road Economic Belt' and a '21st-Century Maritime Silk Road" under the authority of the State Council ("B\&R Document") $)^{14}$. Building on the mystique and history of the ancient Silk Roads and their symbolic role as a connection between cultures, the BRI aims to develop economic cooperation and partnerships with countries along the B\&R.

The overarching aim is to establish an "interest", a "destiny" and a "liability" community through existing bilateral or multilateral ${ }^{15}$ mechanisms ${ }^{16}$ and region-

\footnotetext{
${ }^{10} \mathrm{http}: / /$ europa.eu/rapid/press-release_MEMO-16-4350_en.htm accessed on 22 January 2018.

${ }^{11}$ http://www.europarl.europa.eu/RegData/etudes/STUD/2017/603844/EXPO_STU(2017)603844_E N.pdf accessed on 22 January 2018.

${ }^{12}$ The EU Commission said: "It would build on the EU's groundbreaking approach on its bilateral FTAs and be a major departure from the system of investor-to-State dispute settlement (ISDS) based on ad hoc commercial arbitration." http://trade.ec.europa.eu/doclib/press/index.cfm?id=1608 accessed on 22 February 2018.

${ }^{13}$ Please note that the text is subject to legal review and the numbering may change. In the following, unless another Chapter is specifically mentioned, all Articles referred to from the EUVFTA belong to its Chapter 8 ("Trade in Services, Investment and E-Commerce"), therein Chapter II ("Investment"); for the sake of clarity, please also note that Chapter II is further divided into sections and that the dispute settlement provisions referred to in this study (unless specifically indicated otherwise) are contained in Section 3 ("Resolution of Investment Disputes"). http://trade.ec.europa.eu/doclib/press/index.cfm?id=1437 accessed on 22 February 2018.

${ }^{14}$ http://zhs.mofcom.gov.cn/article/xxfb/201503/20150300926644.shtml accessed on 22 February 2018.

${ }^{15} \mathrm{Up}$ to the end of 2017, China has signed sixteen FTAs with twenty-four countries and regions, covering Asia, Europe, America and Oceania, among which fifteen have come into effect. From the FTAs already entered into, we find that the level of trade liberalization is relatively high, and more than $90 \%$ of all, products are duty-free (a total of about 8,000 ). Against the background of FTAs mentioned above, more than one-third of the imported products could enjoy preferential duty treatment, and most are end-products, which has broadened scope of Chinese consumers' choices. https://www.yidaiyilu.gov.cn/xwzx/bwdt/43783.htm accessed on 22 February 2018.

${ }^{16}$ Such as the Shanghai Cooperation Organization ("SCO"), China and ASEAN Free Trade Area (“CAFTA"), Asia-Pacific Economic Cooperation (“APEC”), Asia Cooperation Dialogue (“ACD”), Conference on Interaction and Confidence-Building Measures in Asia ("CICA"), Central Asia Regional Economic Cooperation (“CAREC”) and other multilateral cooperation mechanism.
} 
al cooperation platforms. It is a far-reaching project that introduces new dynamics, new prospects, but also new challenges to global trade and development cooperation - with their crucial legal and governance linkages. China asserts that it does not seek to establish a completely new cooperation system, but it does propose a $\mathrm{B} \& \mathrm{R}$ international summit forum ${ }^{17}$. In other words, the BRI is a relatively new plan for global governance, which is similar-but not identical-to the traditional regional economic integration plans or other existing partnership arrangements between states. Parallels could be drawn with major global reconstruction initiatives such as the Marshall Plan, the Bretton Woods Agreements and, even, the European Coal and Steel Community. The BRI's stated aim is to help build and foster a regional community of "common destiny", whose harmonious integration and possibility of success depend on the establishment, improvement and completion of a series of legal mechanisms at the local, national, regional and global levels (Zeng, 2016) ${ }^{18}$.

To the best of our knowledge, there has been neither a national nor international establishing legal instruments for the BRI that can indicate the exact legal nature of the plan. One can trace some declaratory origins in the B\&R Document and working report presented at the 19th National People's Congress and a series of related speeches delivered by Chinese authorities on various occasions. The B\&R Document is best seen as a kind of guiding soft law ${ }^{19}$. The Document could also be seen as a statement of policy, a strategic orientation or a form of proclamation paper (Zeng, 2016). In China, the authorities fulfil both executive and legislative roles, and documents and statements are released by senior officials to declare the strategic direction to which they intend to focus their efforts in the coming years. Accordingly, substantial governmental resources and far-reaching multilayered support would be extended to such plans, conforming to the spirit of a particular government policy document. New domestic legal amendments and reforms and the negotiation of new international treaties must undergo lengthy processes. They also tend to work less efficiently than core government documents. As such, Chinese analysts, and experts in Chinese policy, attach weight to government strategy pronouncements such as the B\&R Document.

Since the Participating States of the Belt and Road enjoy comparative advantages (e.g. possession of metals, minerals, oil and gas), the economic complementarity and the abundance of space for trade, multilayered financial and

\footnotetext{
${ }^{17}$ National Development and Reform Commission, Ministry of Commerce, and Ministry of Foreign Affairs, "Vision and Action to Promote the Co-Construction of 'Silk Road Economic Belt' and '21st Century Maritime Silk Road”, Part V “Cooperation Mechanism”.

${ }^{18} \mathrm{Up}$ to 2017 , heads of countries along the Belt and Road have paid forty-three state visits. China has signed fifteen official documents with eleven countries so as to promote development of bilateral relationship. During the Belt and Road Forum for International Cooperation held in May 2017 (heads of eighteen countries along the "Belt and Road" attended the Forum), China signed more than 270 cooperative documents in economy and trade with relevant countries. https://www.yidaiyilu.gov.cn/xwzx/gnxw/43662.htm accessed on 29 January 2018

19“Soft law" refers to a quasi-legal instrument that doesn't carry any legally binding force, or whose legally binding force is weaker than that of traditional laws and regulations.
} 
business cooperation, and strategic synergies form the trade logic for the Initiative $^{20}$. Policy communication has been a crucial pillar for BRI. Another central aspect of the initiative is investment and trade cooperation ${ }^{21}$. The foremost priority, however, is infrastructure development and connectivity-which, arguably, pave the way and often "compel" the growth of trade and investment. Under BRI, a unified, comprehensive transport coordination mechanism will be put in place to maximize the international transportation facilitation and set solid foundations for the realization of the vision and of its multidimensional interconnections. In addition to all of the above, the BRI advances the co-construction of large-scale energy infrastructure projects and communication trunk networks, including a cross-border fiber-optic "backbone".

The Initiative puts forward a dynamic platform of regional and international infrastructure development and upgrading. The core aim of the policy-makers driving BRI is to construct, or reconstruct, trade channels, improve connections and advance those projects and synergies required to ensure free movement along the $\mathrm{B} \& \mathrm{R}$. The cooperation of the host governments is essential to this aim-and Chinese diplomatic efforts are focused on the need to maintain good relations with host governments, underlining the benefits and the opportunities of the investment, and also the space it opens up for future trade and business development. This is crucial, as some BRI projects have appeared intrusive, at times, as they have touched on core national resources such as energy and transport (Kratz \& Stanzel, 2016; Huang, 2017; Maçães, 2016). Chinese diplomacy-political, economic and commercial-has worked to cushion such concerns and win over public opinion in host countries.

Gao Feng, a spokesman for the MOFCOM, in a press conference held in late January 2018, announced that the advancement of the BRI has entered into a new all-round implementation stage in 2017. The spokesman said MOFCOM would promote the construction of the BRI from the following four perspectives in 2018:

1) To strengthen connections with relevant countries in strategy and planning;

2) To further increase the trade and investment facility level through BITs or multilateral agreements;

3) To continue to improve public services systems and update detailed in-

${ }^{20}$ National Development and Reform Commission, Ministry of Commerce, and Ministry of Foreign Affairs, "Vision and Action to Promote the Co-Construction of 'Silk Road Economic Belt' and '21 Century Maritime Silk Road", Part IV "Cooperation Priority".

${ }^{21}$ China has close trade relationship with countries along the Belt and Road. Standard mutual recognition, facility level, investment cooperation level, as well as import from and export to countries along the Belt and Road have increased significantly. During the first three quarters of 2017, the import from and export to countries along the Belt and Road increased 20.1\%, while those with Russia, India and Malaysia kept the fastest growing rate. Also in the first three quarters in 2017, 2893 new enterprises were established by investors from countries along the "Belt and Road", 34.4\% more that of 2016, while the actual input reached USD 4.24 billion. China has signed various investment and trade agreements with 58 countries. https://www.yidaiyilu.gov.cn/xwzx/gnxw/43662.htm accessed on 22 February 2018. 
vestment guidelines already issued; and

4) To guide undertakings to take precautions against and reduce risks ${ }^{22}$.

Acting as China's top-level department in charge of business, economy and trade both foreign and internal, MOFCOM is the principal driver of the State's foreign trade policy direction. This is reflected in the 2018 Government Report delivered by Premier Li Keqiang ("Premier Li") at the opening ceremony of the First Session of the 13th National People's Congress on 5 March 2018. Premier Li proposed to "enhance international cooperation with respect to BRI". This is underscored by the collaboration in rule-making processes and consultation during the implementation of plans agreed at BRI international cooperation summits. Furthermore, it underlines the need for cooperation to build close partnerships with countries participating in BRI. Frameworks for foreign investment was also placed at the forefront to facilitate foreign direct investment ("FDI") and in addition to freeing trade and investment with the western, inland and coastal areas, thereby creating new space for economic cooperation ${ }^{23}$.

\subsection{The Asia Infrastructure Investment Bank}

Since the commencement of its operation in January 2016, the Asian Infrastructure Investment Bank (“AIIB") has promulgated several instruments and constitutive documents ${ }^{24}$ and has completed its governance structure ${ }^{25}$. It is intended to be a multilateral development bank (“MDB") with similar capacities and scope as institutions such as the World Bank, the European Bank for Reconstruction and Development, or the Development Bank of Latin America-with its own distinct focus. The AIIB currently has eighty-four members and is open to additional applicants. By 2015, the UK and France had both joined, to the dismay of the US, which issued warnings about "a trend of constant accommodation" towards China, and expressed the hope that the UK would push for higher standards (Watt, Lewis, \& Branigan, 2015). On Thursday March $23^{\text {rd }} 2017$ the Bank announced that it had approved thirteen new

\footnotetext{
${ }^{22}$ https://www.yidaiyilu.gov.cn/xwzx/bwdt/45814.htm accessed on 22 February 2018.

${ }^{23}$ https://www.yidaiyilu.gov.cn/xwzx/gnxw/49561.htm accessed on 7 Mar. 2018.

${ }^{24}$ From international law perspective, the AIIB was established on the basis of the Articles of Agreement of the Asia Infrastructure Investment Bank (“AOA"). The AOA as signed on 29 Jun. 2015 in English, Chinese and French which are equally authentic, and came into effect on 25 Dec. 2015. The AIIB's internal legal system arises from the AOA. By-Laws of the Asian Infrastructure Investment Bank ("By-Laws") were adopted under the authority of and are complementary to the AOA. Besides, the By-Laws shall be construed in accordance with the AOA while conflicts arise between the two. Other internal legal rules of the AIIB include Rules of Procedure of Governors, Rules of Procedure of Directors, Code of Conduct for Board Officials, Code of Conduct for Bank Personnel, Employee Regulations, Headquarters Agreement, and Investor Presentation. https://www.aiib.org/en/about-aiib/who-we-are/role-of-law/index.html accessed on 22 February 2018. ${ }^{25}$ The highest decision-making power is vested in the Board of Governors (Article 23 of the AOA). Non-resident Board of Directors is responsible for directing the general operations of AIIB, exercising all the powers delegated by the Board of Governors (Article 26 of the AOA). The President, supported by the senior management team (consisting of the General Council and five Vice Presidents), is elected by shareholders of and heads the AIIB. In order to support the President and Senior Management with respect to AIIB's strategies, policies and general operational issues, an International Advisory Panel was set up.
} 
applicants to join the Bank, including Canada, a major ally of the US ${ }^{26}$. The newly-founded $\mathrm{MDB}$, has, in fact, already obtained triple-A ratings from the world's top credit rating institutions-Moody's $\mathbf{s}^{27}$, Fitch ${ }^{28}$ and Standard and Poor's ${ }^{29}$.

The AIIB is a multilateral organization whose largest stakeholder is China; it is not a Chinese bank. The Chinese State handles AIIB affairs strictly in accordance with international rules, through a Board of Directors with input from an Advisory Board. Until December 2017, among all the twenty-four projects already approved by the AIIB, only one was settled in China (in Beijing).

The Asian Development Bank ("ADB") has estimated that the financial requirement for infrastructure construction in developing countries for the 2010-20 period, will reach 8 trillion USD, and average annual investment could be more than 700 billion USD ${ }^{30}$. China's view is that infrastructure construction is a precondition of sustainable development, and this is the focus of the AIIB.

Three thresholds have to be met for the AIIB to support projects approved by the BRI: 1) whether the project is sustainable; 2) whether it is environmentallyfriendly; and 3) whether it is accepted by the local communities and could bring benefits to them. During the past two years, the AIIB has provided loans of 4.2 billion USD to support twenty-four projects, most of which are located in Asia and Africa. The projects concern, among other things, slum renovation, flood prevention, natural gas pipeline construction, expressways and backroads, broadband networks, electric power systems and other core infrastructure development projects. For example, in June 2017, together with the World Bank, the AIIB committed to provide loans to upgrade slums in Indonesia ${ }^{31}$.

The priorities and core aims of the AIIB include: 1) to hire more professional working staff; 2) to broaden projects for sustainable development and fight against climate change; 3) to approve more projects in Africa; and 4) to encourage more involvement of private funds, while at the same time alleviating sovereign debt ${ }^{32}$.

\subsection{Relationship between the Initiative and the Bank}

During the Conference on Interaction and Confidence-Building Measures in ${ }^{26}$ https://www.reuters.com/article/us-china-aiib/china-led-aiib-approves-13-new-members-canada-join s-idUSKBN16U0CG accessed on 23 March 2018

${ }^{27}$ https://www.moodys.com/credit-ratings/Asian-Infrastructure-Investment-Bank-AIIB-credit-ratin g-825099745 accessed on 22 February 2018.

${ }^{28} \mathrm{https} / / /$ www.fitchratings.com/site/pr/1026413 accessed on 22 February 2018.

${ }^{29} \mathrm{https} / / /$ www.aiib.org/en/news-events/news/2017/_download/20170718_001.pdf accessed on 22 February 2018.

30" AIIB opens to lay down milestone for global economic governance", XINHUANET, 2016, "Statistics from the Asian Development Bank (ADB) show that between 2010 and 2020, around eight trillion USD in investment will be needed in the Asia-Pacific region to improve infrastructure." http://www.xinhuanet.com/english/2016-01/16/c_135015984.htm accessed on 22 February 2018.

31“Indonesia: National Slum Upgrading Project”, AIIB, 2016.

https://www.aiib.org/en/projects/approved/2016/indonesia-national-slum.html accessed on $22 \mathrm{Feb}$ ruary 2018.

${ }^{32}$ https://www.yidaiyilu.gov.cn/xwzx/pdjdt/44477.htm accessed on 22 February 2018. 
Asia ("CICA"), held on 21 May 2014, President Xi Jinping proposed setting up the AIIB on the basis of the construction of the BRI, with the core aim being to contribute to the complementary aims of the prosperous development of the Asian economy and regional security. In this spirit, the Chinese President delineated a vision that is encouraging the much-needed maximization of regional cooperation, trade and synergy ${ }^{33}$, advancing socialization, interdependence, interconnectedness, regional growth and development. From a strategic perspective, the AIIB is a crucial component of the BRI-essential for the vision's success and instrumental for its practical advancement. Furthermore, one could see the relationship between the AIIB and BRI from the following four perspectives:

Firstly, the AIIB has already developed into the second largest multilateral development institution after the World Bank in terms of membership of borrowing countries while the BRI is Chinese driven. Nonetheless, there is great overlap between countries along the $\mathrm{B} \& \mathrm{R}$ and membership of $\mathrm{AIIB}^{34}$.

Secondly, the vision of the AIIB is to accelerate the development of Asian infrastructure and to set up a financing platform, which will help promote the integration of the regional economy. This approach is consistent with and complementary to that of the $\mathrm{BRI}^{35}$.

Thirdly, the AIIB can provide financial support to the BRI. The AIIB was not established specifically to fund BRI schemes, nevertheless, as long as a project approved by the BRI corresponds with the AIIB's investment principles, including international procurement, the Bank will always be ready to lend. Regionally speaking, capital outflow has long been the main threat to Asian economic security. By providing high quality financial services, the AIIB could help to meet the enormous financial requirements of the BRI (Asian Development Bank, 2010), but also help to upgrade the capital utilization rate of Asian countries and attract global capital to the region.

Fourthly, the AIIB will facilitate the establishment of a complete "financial chain" for the BRI. The AIIB could not only help transform the traditional East Asian preference for "safe" deposits over "risky" investment, but also refocus the public business and investment attention from the virtual economy back to the real economy. Together with the Silk Road Fund, the AIIB is able to employ and procure various financial instruments in order to maximize the effectiveness of its capital.

${ }^{33}$ http://www.chinanews.com/cj/2014/05-22/6198502.shtml accessed on 22 February 2018.

${ }^{34} \mathrm{AOA}$ of AIIB, Articles 2 \& 3; Article 1, “... 2. Wherever used in this Agreement, references to "Asia" and "region" shall include the geographical regions and composition classified as Asia and Oceania by the United Nations, except as otherwise decided by the Board of Governors..." https://www.aiib.org/en/about-aiib/basic-documents/_download/articles-of-agreement/basic_docu ment_english-bank_articles_of_agreement.pdf accessed on 22 February 2018.

${ }^{35} \mathrm{AOA}$ of AIIB, Article 1," The purpose of the Bank shall be to: 1) foster sustainable economic development, create wealth and improve infrastructure connectivity in Asia by investing in infrastructure and other productive sectors; and ii) promote regional cooperation and partnership in addressing development challenges by working in close collaboration with other multilateral and bilaterai development institutions ...”

https://www.aiib.org/en/about-aiib/basic-documents/_download/articles-of-agreement/basic_docu ment_english-bank_articles_of_agreement.pdf accessed on 22 February 2018. 


\section{Legal Aspects of the Initiative}

\subsection{Types of Legal Arrangements}

China has signed numerous agreements and treaties with countries and regions along the Belt \& Road ever since the promulgation of the BRI.

\section{Free Trade Zones}

The Chinese Communist Party proclaimed its decision to "rapidly implement a free trade zone strategy" at its 18th National Congress in 2012. The creation of these zones is a prerequisite for the coordination of both domestic and international structures and the development of a higher level of economic cooperation and growth. By signing free trade zone agreements, the Chinese market has come to integrate more deeply with the economies of BRI partner countries. The level of integration and the depth of the cooperation is much deeper than that which was achieved via membership of the WTO. As a result of this multifaceted deepening, a more advantageous cooperation environment has been fostered for Chinese foreign trade and investment.

By September 2017, China had signed free trade zone agreements with twenty countries, of which twelve were located along the B\&R. To date, fourteen free trade agreements and three preferential trade arrangements have been implemented ${ }^{36}$. Since 2014, agreements have been signed or entered into effect between China and Switzerland, South Korea and Georgia, extending the Chinese free trade zone network to Europe, Northeast Asia and Eurasia. Furthermore, new breakthroughs in areas of environmental policy, intellectual property rights, competition policy, electronic business activity and regulation, economic cooperation, transparency and many other topics have generated heated domestic discussion in partner countries. This was particularly true in the cases of the free trade zone agreements between China, South Korea and Australia.

\section{Bilateral Trade Agreements}

During the 4th China International Economic Cooperation "GoGlobal" Forum, held in May 2016, Mr. Han Yong, Commercial Counselor of the MOFCOM, announced that China had signed BITs with fifty-six countries along the B\&R. Some key trends to observe include: 1) the scope of overseas investment has been expanding continuously; 2) the advancement of joint infrastructure investments and inter-connectedness has been increasingly welcomed across the $\mathrm{B} \& \mathrm{R} ; 3$ ) international production capacity cooperation has been steadily pushed forward, especially in the areas of high-speed railway development and interconnectivity, and electricity generation; and 4) regional economic and trade arrangements have been actively built-up ${ }^{37}$.

\section{Tax Arrangements}

Acting as the legal basis for tax cooperation between countries, tax agreements ${ }^{36} \mathrm{http}: / /$ www.mofcom.gov.cn/article/i/jyil/m/201709/20170902645600.shtml accessed on 22 February 2018.

${ }^{37}$ http://www.mofcom.gov.cn/article/difang/201606/20160601331178.shtml accessed on 22 February 2018. 
are the crucial guarantee for undertakings to go overseas. Ever since the BRI came to public attention, the pace of negotiating and signing tax agreements between China and other countries has accelerated significantly. By May 2017, China had entered into bilateral tax agreements, arrangements or protocols with 106 countries, fifty-four of which are located along the $B \& R^{38}$. Tax agreements play an active role in coordinating cross-border tax issues, protecting projects, investments and businesses from double taxation and better protecting the rights and interests relating to the undertakings of both contracting parties. Furthermore, such agreements are important in terms of facilitating the swifter and more efficient resolution of any tax disputes arising.

\section{Agreements and Cooperation in other areas}

Considerable success has been marked in cultural and ethnic exchanges, too. In fact, all the countries along the $\mathrm{B} \& \mathrm{R}$ have signed intergovernmental agreements on cultural exchange and cooperation with China. Every two to three years, detailed and actionable implementation plans are laid out and followed through. At the same time, a series of tailored regional dialogue platforms have been established to increase the appeal of cultural cooperation between Participating States on different levels ${ }^{39}$.

In the sphere of transport and logistics, more than 130 bilateral or regional transport agreements have been signed, according to the latest update released by the Ministry of Transport in April 2017. One example is the Shanghai Cooperation Organization (SCO) Intergovernmental Agreement on Creating Beneficial Conditions for International Road Transportation, which covers areas of railway, highway, maritime, civil aviation and postal transport. Projects focused on the transport industry are mainly concentrated around the "six economic corridors" of the $\mathrm{B} \& \mathrm{R}^{40}$.

China has also signed technology cooperation agreements with almost fifty countries along the $\mathrm{B} \& \mathrm{R}$, including the China-ASEAN Science and Technology Partnership Program ${ }^{41,42}$. Currently, the global economy is in a gradual recovery phase, and innovation in science and technology plays a pivotal role in supporting this.

Lastly, twenty-one countries along the $\mathrm{B} \& \mathrm{R}$ have signed standardization cooperation agreements with China. Through deepening cooperation and mutual beneficial cooperation and connectivity, the Standardization Administration of China and standardization organizations from important countries along the $\mathrm{B} \& \mathrm{R}$ will try to adopt common standards so as to reduce, or even eliminate, trade barriers ${ }^{43}$.

\footnotetext{
${ }^{38}$ http://www.chinatax.gov.cn/n810341/n810780/c2605766/content.html accessed on 22 February 2018.

${ }^{39}$ http://china.cnr.cn/news/20170512/t20170512_523750850.shtml accessed on 22 February 2018.

${ }^{40}$ http://www.ce.cn/xwzx/gnsz/gdxw/201704/27/t20170427_22374181.shtml accessed on 22 February 2018.

${ }^{41}$ http://www.cistc.gov.cn/China-ASEAN/ accessed on 22 February 2018.

${ }^{42}$ http://www.thepaper.cn/newsDetail_forward_1534183 accessed on 22 February 2018.

${ }^{43}$ http://paper.ce.cn/jjrb/html/2016-09/13/content_311605.htm accessed on 22 February 2018.
} 


\subsection{BRI \& AIIB Membership Comparison and Complementarity}

\section{The $B R I^{44}$}

There are sixty-five countries along the "Belt and Road", including Mongolia (East Asia), Singapore, Malaysia, Indonesia, Myanmar, Thailand, Lao PDR, Cambodia, Vietnam, Brunei Darussalam, Philippines (the ten countries of the ASEAN), Iran, Iraq, Turkey, Syria, Jordan, Lebanon, Israel, Palestine, Saudi Arabia, Yemen, Oman, United Arab Emirates, Qatar, Kuwait, Bahrain, Greece, Cyprus, Sinai Peninsula (eighteen South Asian countries), India, Pakistan, Bangladesh, Afghanistan, Sri Lanka, Maldives, Nepal, Kingdom of Bhutan (eight countries from South Asia), Kazakhstan, Uzbekistan, Turkmenistan, Tajikistan, Kyrgyzstan (five Middle Asian countries), Russia, Ukraine, Republic of Belarus, Georgia, Republic of Azerbaijan, Armenia, Moldova (seven countries from the CIS), Poland, Republic of Lithuania, Estonia, Latvia, Czech Republic, Slovakia, Hungary, Slovenia, Croatia, Bosnia and Herzegovina, Serbia, Albania, Romania, Bulgaria and Macedonia (sixteen East European countries).

\section{The $A I I B^{45}$}

As of $22^{\text {nd }}$ of March 2018, the AIIB's total approved membership had reached eighty-four. Regional ${ }^{46}$ members of AIIB include Afghanistan, Australia, Republic of Azerbaijan, Bangladesh, Brunei Darussalam, Cambodia, China, Fiji, Georgia, Hong Kong China, India, Indonesia, Iran, Israel, Jordan, Kazakhstan, Korea, Kyrgyz Republic, Lao PDR, Malaysia, Maldives, Mongolia, Myanmar, Nepal, New Zealand, Oman, Pakistan, Philippines, Qatar, Russia, Samoa, Saudi Arabia, Singapore, Sri Lanka, Tajikistan, Thailand, Timor-Leste, Turkey, United Arab Emirates, Uzbekistan, Vanuatu and Vietnam (forty-two regional members), having subscribed USD 73,731.7 million (76.8\%) totally and together enjoying 847,705 votes (75.2\%). Non-regional members include Austria, Canada, Denmark, Egypt, Ethiopia, Finland, France, Germany, Hungary, Iceland, Ireland, Italy, Luxembourg, Malta, Netherlands, Norway, Poland, Portugal, Spain, Sweden, Switzerland and United Kingdom (twenty-two non-regional members), who have subscribed USD 22,267.4 million (23.2\%) in total and could exercise $24.8 \%$ of all the voting rights together. Besides, Armenia, Bahrain, Cook Islands, Cyprus, Kuwait and Tonga (six in total) are regional prospective members ${ }^{47}$, while Argentina, Republic of Belarus, Belgium, Bolivia, Brazil, Chile, Ecuador, Greece, Madagascar, Peru, Romania, South Africa, Sudan and Venezuela (fourteen in total) are non-regional prospective members.

\section{Several observations that can be made:}

1) Geographically, Participating States of the BRI are mainly from regional ${ }^{44}$ http://silkroad.news.cn/2017/1225/76186.shtml accessed on 22 February 2018.

${ }^{45}$ AIIB, "Members and Prospective Members of the Bank". https://www.aiib.org/en/about-aiib/governance/members-of-bank/index.html accessed on 22 February 2018.

${ }^{46} \mathrm{AOA}$ of AIIB, Article 1(2), “... 'Asia' and 'region' shall include the geographical regions and composition classified as Asia and Oceania by the United Nations, except as otherwise decided by the Board of Governors."

${ }^{47}$ Only after they complete domestic processes and deposit the first installment of capital with AIIB will prospective members officially join AIIB. 
Eurasian and the MENA countries, while those having already joined the AIIB could be from any country from all continents but Antarctica. In other words, the AIIB consists of a wider membership than the Initiative and has attracted almost twenty more countries and regions than the BRI alone.

2) There is great overlap between the membership of the BRI and that of AIIB. To be more specific, the ten ASEAN countries have participated in both. Five out of the seven countries of the CIS are both members of the Initiative and the AIIB, while Ukraine and Moldova have not yet applied to participate in the AIIB.

3) On the basis of geographical regions and countries classified as parts of Asia and Oceania by the United Nations ${ }^{48}$, as well as members listed in Part A of Schedule A of the Articles of Agreement ("AOA") of the AIIB, the bank divides its official members into regional and non-regional ones. The number of non-regional members-twenty-two-effectively accounts for almost 50\% of that of the forty-two regional members. To date, only two out of the twenty-two official non-regional countries of the AIIB are along the B\&R-Hungary and Poland.

4) European countries covered by the Initiative are mainly from the east and south east. In comparison, far more countries from central and western Europe have already played an active role in the AIIB and its operations-such as the United Kingdom, Germany, France, The Netherlands, Ireland, Finland, and Switzerland. We can refer to Germany, France and the United Kingdom in a bit more detail to underline this point. The three more influential EU member states became members of the AIIB on 25 December 2015 (Germany and UK) and on 16 June 2016 (France). Germany is enjoying a 4.3\% voting power, France 3.3\% and the UK $3 \%$, percentages that are much higher than that of most regional members, with a few notable exceptions such as Australia (3.5\%), China (27\%), India (7.7\%), Indonesia (3.3\%), Korea (3.6\%) and Russia (6.1\%). Furthermore, in December 2017, the United Kingdom signed an agreement to contribute USD 50 million to the AIIB's Special Fund for Project Preparation ${ }^{49}$. During Prime Minister Theresa May's visit to China at the end of January 2018, a "Memorandum of CNY 10 Billion Credit Loan for B\&R Initiative Projects" was also signed between the China Development Bank and the Standard Chartered Bank ${ }^{50}$. This reflects the importance attached by leading European economic actors to the AIIB. The overall visit and approach of the British Prime Minister underlines the United Kingdom's decision to cooperate more closely with China, especially against the background of the country's decision to leave the European Union.

${ }^{48} \mathrm{AOA}$ of AIIB, Article 1.

https://www.aiib.org/en/about-aiib/basic-documents/_download/articles-of-agreement/basic_docu ment_english-bank_articles_of_agreement.pdf accessed on 22 February 2018.

${ }^{49}$ AIIB, “UK Government Pledges US\$50 million to AIIB Project Preparation Special Fund”, 2017. https://www.aiib.org/en/news-events/news/2017/20171216_001.html accessed on 22 February 2018.

${ }^{50}$ Notably, however, the British PM avoided the signing of a larger MoU on the BRI, which was placed at \$900bn. Jessica Elgot, “Theresa May's China visit offers little to silence critics at home”, The Guardian, 2018.

https://www.theguardian.com/politics/2018/feb/02/theresa-may-china-visit-little-silence-critics-ho me accessed on 22 February 2018. 
5) Hong Kong also participated in the negotiation of the articles of association of AIIB, through China, and became a regional member on 7 June 2017, enjoying $0.9 \%$ of the voting rights. Its contribution to the initiative is linked with its role as a leading Asian financial hub.

6) Korea joined the AIIB on 25 December 2015, even before the commencement of the Bank's activities in January 2016. What is more, it committed USD 3,738 million and could enjoy $3.6 \%$ of all the voting power, larger than that of France and the UK. This shows Korea's active initiative in participating in China's development proposal, even though construction of a potential community between China, Korea and Japan is not a simple equation, given their difficult histories, diverging geopolitical interests and differing threat perceptions.

It is therefore clear that the BRI is not the AIIB, and it is different in several fundamental legal levels. That being said, these two international efforts are closely connected and function collectively to achieve a great level of complementarity with one another. The BRI is different in that it is a "grand policy" or transnational strategic effort whose aim is to organize and facilitate closer economic and trade relationship between Asia, Europe and Africa. The AIIB, on the other hand, is an Asian multilateral development bank, with establishing legal instruments, an accession process and explicit administrative regulations and legal framework. The long-term mission of the AIIB is to accelerate the integration of Asian regional economies, and hence the deep complementarity with the $B \& R$ roadmap. Even though the AIIB was not established specifically for the BRI, as long as a project proposed by the BRI corresponds to the AIIB's investment strategy, the AIIB will almost always be ready to support, as was explained by Mr. Jin Liqun, President of the AIIB ${ }^{51}$.

\subsection{Foundational Legal Principles}

\section{The Concept of Harmony}

The word of "harmony" - not to be confused with "harmonization"- has been mentioned three times in the B\&R Document. It is not clear how harmony will be given agency as a legal concept. However, indications of its application may well evolve in Chinese international trade law just as the concept of "efficiency" has in American corporate law (Hamermesh, 2006).

1) When introducing the background of the BRI, the interconnection and interworking projects will promote communications between people from countries along the $\mathrm{B} \& \mathrm{R}$ so as to facilitate mutual understanding and trust and to live a harmonious, peaceful and prosperous life.

2) Harmonious inclusiveness is one of the five foundational principles of the BRI. The initiative advocates cultural and politico-economic diversity. The BRI respects and accepts each country's free choice of its own path to development and growth. It promotes communication, exchange and socialization between

${ }^{51}$ Belt and Road Portal, YIDAIYILU.gov.cn, "Achievement Already Made by the AIIB Makes the Chinese Satisfied After Having Operated for Two Years", 2018,

https://www.yidaiyilu.gov.cn/xwzx/pdjdt/44477.htm accessed on 7 March 2018. 
different cultures and worldviews-seeking to maximize the space for harmony and cooperation between parties, to help resolve differences, enhance mutual understanding, and contribute to peaceful co-existence across the Belt and Road by ensuring that the focus remains on the common opportunities, and the space for shared progress and prosperity.

3) Communication and cooperation between NGOs from countries along the $\mathrm{B} \& \mathrm{R}$ and their key exponents is also being promoted ${ }^{52}$. Some of the core objectives include: to advance medical education, to alleviate poverty, to protect biodiversity, to enhance awareness and contribute to the advancement of environmentally-friendly social and corporate behavior or policy, along with a series of other socio-economic causes, charitable and philanthropic activities. International cultural and media exchanges are also encouraged, with great importance being attached to digital media and communication platforms and the role of social media and other innovative communication and information platforms. The core concept is that enhanced cooperation in these spheres can contribute to more aware and better-informed societies, as well as a higher standard of ecological behavior and the adoption of environmentally-friendly practices with a greater sensitivity towards the use of resources and the protection of the environment (Winter, 2016; Faculty of Law, Oxford University, 2017). In other words advancing harmony between human behavior and nature, thereby protecting our natural environment and shared habitat.

In the working report delivered by President Xi Jinping to the 19th National Congress of the Chinese Communist Party, titled: "Securing a Decisive Victory in Building a Moderately Prosperous Society in All Aspects and Striving for the Great Success of Socialism with Chinese Characteristics for a New Era" in October 2017, we note that "harmony" (or harmonization) was mentioned seven times. Namely: 1) During the past year, the Communist Party has managed to deal with eight pieces of work to promote government-building and governance innovation and maintain social harmony and stability. 2) The stable and healthy development of the economy, together with a harmonious environment has been achieved so as to get ready for the 19th National Congress. 3) When proposing to construct a healthy China, a harmonious doctor-patient relationship shall be established. 4) Since China is a unified multi-ethnic country, living, working and developing harmoniously among all the nationalities will make the Chinese family happier and more peaceful. 5) In accordance with the basic policies of the Communist Party's religious work, religious affairs will be administered according to laws and regulations, while harmonious relationship between different religions will be promoted. 6) Chief executives and authorities of the Hong Kong and Macau Special Administrative Regions will be fully supported in order to develop their economies, improve people's livelihood, advance democracy and promote harmony. 7) All the Chinese people are called upon to follow more

${ }^{52}$ The European Think-tank Network on China, "Europe and China's New Silk Roads", 2016, p.7. www.clingendael.org/sites/default/files/pdfs/Europe_and_Chinas_New_Silk_Roads_0.pdf accessed on 22 February 2018. 
closely the lead given by the Communist Party of China, steered by Comrade Xi Jinping, and strive together for a better life with one heart and one mind, forge ahead, try every effort to achieve the goal of social development and make unremitting efforts to achieve the grand dream of "two hundred years", establish a prosperous, democratic, cultural and harmonious society, and bring about a great rejuvenation of the Chinese nation.

This list underlines the Chinese commitment to the concept of harmony, and the belief in its social, economic and political dimensions. It sheds further light on Chinese efforts to apply this concept to the BRI and their attempts to spread it across the $\mathrm{B} \& \mathrm{R}$ countries.

Stability is a pre-condition and guarantee of both economic and social development ${ }^{53}$. Internationally, it refers to relationships with other countries on the basis of the five principles of peaceful coexistence. Domestically, a united country with harmonious relationships between the fifty-six nations of the $B \& R$ plays a key role. Furthermore, harmony between society and nature is essential when looking for way to achieve stability.

This ethic could also be observed in the manner in which the Chinese traditionally resolve commercial and business disputes. This is totally different from Western cultures, which tends to be highly litigious. In China, the private resolution of disputes is preferred, unless the gravity of the situation dictates a different approach.

\section{Cooperation}

"Cooperation" is mentioned 138 times in the B\&R Document. It is peaceful cooperation that encapsulated the spirit of the ancient Silk Road, promoting the progress of human civilization as well as the joint prosperity and development of all the countries along the route. It is the symbol of communication and cooperation between the eastern and western countries. For the Chinese, there is hardly any word or concept as important as cooperation in today's world and international landscape. It is cooperation that focuses the attention of peoples and nations on trade activities; it is cooperation that has helped to establish a modern financial system; economic interdependence and cooperation have in turned helped us avoid another world war; while it is also cooperation that will ultimately connect the word and help achieve common development. While not an exclusively Chinese approach, the roots of the concept of cooperation in China run deep, and they carry historical significance, social applicability and underpin the Chinese state's worldview.

\section{Trade}

With the rise of trade fragmentation, digital currency platforms, and national re-orientations such as Brexit or the unilateralism of the present US administration, the patterns of international investment and trade, as well as the multilateral rules that govern them, are undergoing profound redefinition. The BRI is a strong advocate of maintaining the free trade system and an open international

${ }^{53}$ http://business.sohu.com/20130603/n377850667.shtml accessed on 22 February 2018. 
economy. Free trade is one of the priorities of the Participating States of the B\&R. Facilitation of investment and trade are to be promoted, and tariffs are to be eliminated so as to establish a regional and international environment friendly to business. B\&R countries are strongly encouraged to set up free trade areas so that the full cooperative potential can be identified and realized. This is an exercise that could bring manifold benefits to countries and regions through the efficient allocation of resources, improved transport and logistics arrangements, economies of scale, and so forth. Under the BRI vision, the scope of trade will be broadened, and trade structures will be optimized to explore new growth avenues and achieve an optimal balance of trade and progress.

\section{Development}

The word "Development" was mentioned fifteen times in the "B\&R Document". In the present era, with its multifaceted challenges, the themes of peace, development, cooperation and win-win approaches are ever timely and necessary. Therefore, the rediscovery and promotion of the ancient Silk Road's spirit is particularly relevant today, as we are faced with a sluggish global economic recovery, and a series of complicated trans-border and regional crises and conflicts. Development shortcomings and inequality remain serious challenges that virtually all countries and governments around the world must address and overcome.

The BRI devotes itself to the enhanced interconnection by land and sea of Asia, Europe and Africa. The core aim is to establish a network that will help countries along the $\mathrm{B} \& \mathrm{R}$ to achieve inclusive, autonomous, balanced and sustainable development. According to the Chinese vision, the construction of the BRI will contribute directly to the economic prosperity of the B\&R countries; it will enhance and accelerate regional economic cooperation between the $B \& R$ countries, and also strengthen ties between diverse cultures, contributing to peaceful development: a noble and ambitious pursuit, but a challenging one, in this rapidly changing world, with its increasing crises, tensions and asymmetries.

\section{Dispute Resolution Mechanism}

\subsection{The Urgent Need for BRI Dispute Resolution Mechanism}

This new, outward and more forceful Chinese foreign development and trade policy model creates multiple opportunities, opens new trade routes, paves new avenues for economic cooperation and, in a way, compels openness. From central Europe, to the greater Middle East, Africa and Asia, the Chinese are strategically investing in ports, airports, energy and other critical infrastructure to establish logistics bases, trading hubs and new or upgraded transport routes. This is a far-reaching program, and of course, it will not be without challenges.

With the help of the BRI, China seeks to advance greater peace, stability, joint progress and prosperity. But, as we know, there are always challenges associated with sweeping transformations, and, especially when dealing with colossal investments or co-investments concerning critical national infrastructures such as 
ports, airports, railways, pipelines and energy generation and distribution. In this respect, while we recognize the Chinese vision's commitment to, and pursuit of, "harmony", we also strongly suggest that it is necessary to include ISDS provisions and mediation within China's model. Harmony is an idea; a means of dispute resolution is needed to realize it in the world.

\section{We can therefore make the following observations.}

Firstly, civil and business judicial assistance and cooperation between countries along the $\mathrm{B} \& \mathrm{R}$ does not work very well. To take China as an example, among all the sixty-five Participating States of the B\&R, only seven have signed civil (commercial) judicial assistance treaties with $\mathrm{China}^{54}$. In other words, in most cases, domestic judgements or decisions, will neither be recognized nor enforced in other countries.

Secondly, to date, there is no multilateral dispute resolution mechanism in place that could effectively resolve most of the disputes that may arise between countries along the $\mathrm{B} \& \mathrm{R}$. As for bilateral agreements, due to extensive differences in the substance of bilateral agreements, there is no effective or unified dispute resolution mechanism in place. When a dispute arises, other disagreements will also surface. These may include the matters that should be addressed by an arbitral tribunal, which tribunal will be chosen, the substantive and procedural law that will be applied, and so on.

Thirdly, Participating States of the B\&R understand and explain international rules differently ${ }^{55}$. Normative and practical approaches to the legal and regulatory frameworks are often divergent and mismatched.

Therefore, it becomes clear that the present dispute resolution mechanisms cannot match the distinct development and nature of the BRI, and its diverse composition. We also note that, given the nature of the Initiative and the predominant cultural characteristics of the Chinese system, any approaches that do not have mediation at their core will be problematic.

\subsection{Conventional Alternative Dispute Resolution Methods}

Broadly speaking, disputes could be resolved in a conventional way, either by litigation or ADR mechanisms such as arbitration, conciliation and mediation. Usually, domestic litigation tends to be a matter for national jurisdictions. In contrast, ADR is a way through which parties can privately settle disputes either with or without the help of an independent third party. ADR has been rapidly gaining popularity in recent years. One reason for this is the huge backlog of cases in traditional international courts. The costs are high, both in time and resources, the process painfully slow, the outcome uncertain, the risks high and public exposure considerable. ADR, by contrast, maximizes the discretion of ${ }^{54}$ http://www.fmprc.gov.cn/web/ziliao_674904/tytj_674911/wgdwdjdsfhzty_674917/t1215630.shtml accessed on 22 February 2018.

${ }^{55}$ As repeatedly emphasized throughout the paper, that through this exercise and contribution, we are trying to find the normative features of the legal system emanating from the BRI and China. Our core argument is that the heart of the much-needed legal system has to be dispute resolution, with a strong mediation component. 
parties and offers a faster, more efficient, more discreet, more economic, more balanced and more easily managed process. Mediation, especially in the case of the BRI, may hold the key to the maximization of harmony and the minimization of bureaucratic and legal burdens. Even though the agreements must rest on a solid dispute resolution framework, the optimal solutions will most likely arise through the prioritization of a tailored mediation mechanism within a distinct BRI ADR structure.

Arbitration is a way to resolve commercial disputes with help of arbitrator(s). The arbitral tribunal will make an award that is final and legally binding on both parties.

If both parties would like to attempt to mend their relationship even after disagreement has arisen, then conciliation may provide a good option. The conciliator meets both parties separately and together to resolve their differences by lowering tensions, improving communications, interpreting issues and encouraging parties to explore potential solutions.

Lastly, facilitated rather than directed by the mediator, mediation is a "partycentered" process to help two sides find an optimal solution. The whole process is confidential, and the parties resorting to mediation maintain their agency.

\subsection{Existing International Dispute Resolution Mechanisms}

Some of the prevailing dispute resolution mechanisms across the world will be presented and analyzed here in order to provide useful references for the establishment of that against the background of the BRI.

\section{European Union Courts}

One of the most distinctive features of the EU is that it has its own independent supranational judicial system, including the European Court of Justice, which is authorized to resolve disputes between member states; explain, interpret and enforce the European treaties, and so forth. It is the highest court within the EU as far as all matters regarding the enforcement of European Union Law and its interpretation are concerned.

\section{WTO Dispute Settlement Body}

Through amending the Understanding on Rules and Procedures Governing the Settlement of Disputes ("DSU"), the WTO set up its own quasi-judicial dispute settlement mechanism. The Dispute Settlement Body ("DSB") is a permanent entity that was established in parallel to the development of the other internal WTO institutions. It is equipped with the rules and guidelines needed to guarantee the independence of the members of both a panel and the Appellate Body. The DSB benefits from a unique decision-making process known as the "negative" or "reverse" consensus principle. This means that at the three important DSU stages of the dispute settlement process (i.e. establishment, adoption and retaliation), the DSB must automatically approve the decision and take it forward unless there is a consensus by the members against it (Articles 6.1, 16.4, 17.14 and 22.6 of the DSU). The special voting mechanism of DSB has helped to 
avoid tedious procedures, while the two-level remedy (the panel and Appellate Body) increase judicial effectiveness, safeguarding the rights and interests of members. Effectively, consultation is fully respected and supported before the panel.

\section{Dispute settlement provisions in the NAFTA}

The North American Free Trade Agreement ("NAFTA"), which came into effect in 1994, created one of the world's largest free trade zones. It laid the foundations for economic cooperation between Canada, the US and Mexico. NAFTA is equipped with a well-established dispute resolution mechanism, consisting of private dispute resolution, financial services dispute resolution, settlement between a party and an investor of another party, as well as antidumping and countervailing duty determinations. NAFTA also aims to promote cooperation of the three member countries in labor rights and environmental protection. The advantages of other international dispute resolution mechanisms have been incorporated by NAFTA. Established on the basis of arbitration, the dispute resolution mechanism under NAFTA has quasi-judicial characteristic.

\section{The Energy Charter Treaty: Guidance for Mediation}

The Energy Charter Treaty ("ECT") Secretariat has recognized states' increasing calls to find alternatives to arbitration, and this has led to an increase in the number of cases resulting in settlement agreements, as well as calls for the incorporation of mediation into its dispute resolution system. Therefore, the ECT developed an innovative and effective Mediation Guideline approved in 2016 to incorporate and support the use of mediation within the existing treaty.

\section{Dispute settlement mechanism between China and ASEAN ${ }^{56}$}

The China-ASEAN Free Trade Area is a trading zone established between China and the ASEAN countries that began to operate officially on 1 January 2010. It is the largest free trade area established by developing countries. Article 11 of the Framework Agreement on Comprehensive Economic Cooperation between the Association of Southeast Asian Nations and the People's Republic of China required that formal dispute settlement procedures and mechanisms were to be established within one year of the date of entry into force of the Agreement, before which amicable settlement by consultations or mediation is also allowed. On 1 January 2005 the Agreement on Dispute Settlement Mechanism of the Framework Agreement on Comprehensive Economic Cooperation between the People's Republic of China and the Association of Southeast Asian Nations ("China-ASEAN Dispute Settlement Agreement") came into effect. The China-ASEAN Dispute Settlement Agreement also provides a comprehensive system for dispute resolution, encompassing consultations, conciliation, mediation and, primarily, arbitration. However, one can only turn to an ad hoc arbitral tribunal, as there is no permanent arbitral institution in place.

\subsection{Mapping Elements of the Chinese Approach}

In the afternoon of 23 January 2018, the Second Conference of the Central ${ }^{56} \mathrm{http} / / /$ www.cn-asean.org/uploadfile/2016/0520/20160520102528411.pdf accessed on 22 February 2018. 
"All-round and Deep Reform Leading Team" (also known as the "Conference") was held in Beijing. President Xi Jinping delivered the keynote speech. The Conference deliberated and approved the "Opinions on Establishing the ' $B \& R$ Initiative' Dispute Resolution Mechanism and Institute"

They proposed the establishment of the BRI Dispute Resolution Mechanism and Institute, under the principle of achieving shared growth through cooperation and dialogue. In accordance with the existing Chinese judicial, arbitral and mediation institutes, the new BRI structures will absorb and integrate legal services, structures and resources from both domestic and international sources. The aim is to establish a broad, diversified and all-inclusive mechanism that efficiently connects litigation, arbitration and mediation. The new mechanism and the corresponding institute aim to properly settle trade and investment disputes arising in relation to the BRI. Such disputes and resolution processes will be advanced in accordance with the established laws and regulations with a view to equally protect rights and interests of both domestic and foreign parties-in order to establish a stable, fair and transparent business environment.

As early as 14 July 2017, a seminar on "Legal Issues of the 'B\&R Initiative' Construction" was being held in Beijing. Mrs. Wang Shumei, Deputy Presiding Judge of the Fourth Civil Tribunal at the Supreme People's Court, delivered a speech, and announced that the Supreme People's Court (Chinese Supreme Court-leading national judicial institution) would focus on the following three tasks ${ }^{58}$

1) To establish the BRI mechanism and institute in a way that ensures the solidity of its legal structure and foundations; and to ensure that it is fitted with the appropriate guarantees, instruments and mechanisms to deliver efficiently the all-round services needed. The court is currently doing research into how to best establish a multi-level dispute resolution mechanism combining mediation, litigation and arbitration. It aims to upgrade China's power of discourse and initiative in this crucial sphere.

2) To improve the relevant legal policies, and rapidly publish judicial interpretations and clarifications, as needed; in addition, to explain arbitration, release exemplary cases, explore the best way to recognize and enforce foreign judgments and to demonstrate the necessity of compiling a code to deal with the civil relationships with foreign entities.

3) To strengthen and enrich the setting up of the BRI team with as much expertise as possible, thereby broadening and highlighting the influence of the Chinese judicial system. The Supreme People's Court will co-organize the setting up of such a talent platform and pool with the relevant ministries and commissions. It will promote cooperation between judicial centers, in order to construct a case-sharing platform that will be a valuable shared resource.

In July 2015, the "Several Opinions of the Supreme People's Court to Provide Judicial Services and Guarantee for Construction of "One Belt, One Road" were ${ }^{57}$ https://www.yidaiyilu.gov.cn/xwzx/xgcdt/45583.htm accessed on 22 February 2018.

${ }^{58}$ http://jjckb.xinhuanet.com/2017-07/14/c_136443750.htm accessed on 22 February 2018. 
promulgated by the Supreme People's Court ${ }^{59}$. Besides fulfilling the role of a judicial institute, people's courts shall also actively advocate and participate in improving the current mechanism, while at the same time try to put forward suggestions for investment dispute resolution, as a kind of expert feedback loop.

\subsection{The Concept of Dispute Regulation}

When it comes to how to establish a dispute settlement mechanism that could fully fit the implementation of the BRI, some basic principles shall be adhered to, which are: procedural justice, party self-determination, the neutrality of the person or institution in charge of the resolution, the equal treatment of all parties and protection-guarantees of the full and free participation by all parties in the process.

It can be observed that numerous countries along the $B \& R$ have a) different geo-economic, geopolitical and geostrategic agendas; b) different national legal environments and are signatories to diverse international legal treaties, groups and trading blocs; c) diverse religious backgrounds, traditions and ethno-cultural compositions; d) different economic systems and standing; and e) some of them have endured wars for many years, that have left traumas, painful collective memories, and a degree of fragility-which raises both internal and external security concerns. In light of this complexity, and series of sensitivities and delicate imbalances, new requirements are to be put forward for the dispute resolution mechanism against the dynamic BRI background.

As detailed in this paper, the goal of the Initiative at its early stages is to focus on infrastructure development in the sphere of transport, such as highways, ports, airports, and railway interconnections, as well as energy infrastructures such as pipelines and liquid natural gas depositories; the middle-term target is the establishment of a relatively mature free trade area. The potential investment and trade system that will be established under the B\&R Initiative may be different from traditional trade agreements, which focus on market entry and preferential treatment. Rather, it will place greater emphasis on a new economic cooperation framework that will aim to be simultaneously more diverse, open and inclusive. It will be a wide-ranging system that goes beyond elimination of tariffs, and includes strategic co-investments, long-term economic partnerships, pivotal energy agreements, crucial synergies, and platforms for joint investments in industries such as ICT.

This paper has highlighted the added value of mediation within the demanding sphere of ISDSs and, especially, in the sui generis case of the BRI. In the following concluding lines, the paper will suggest some tangible policy steps that may help establish an efficient dispute resolution mechanism in the BRI context. This is not an attempt to re-invent the wheel. Instead, we will argue that the answer is to employ best practices and make full use of existing international mul-

${ }^{59}$ The Supreme People's Court of the People's Republic of China, "Several Opinions of the Supreme People's Court to Provide Judicial Services and Guarantee for Construction of 'One Belt, One Road", 2016. http://www.court.gov.cn/zixun-xiangqing-14900.html accessed on 22 February 2018. 
tilateral tools and mechanisms, while at the same time taking specific characteristics of the Initiative into account. A smart adaptation and incorporation of the ISDS system could be at the core of the BRI and the legal norms that define it.

\section{$A$ unified dispute resolution mechanism is optimal}

Compared with mechanisms such as the WTO and NAFTA, which provide different resolution methods, a unified approach is not only much easier to manage, but also would reduce litigation costs and facilitate implementation. Furthermore, a very light appeals mechanism would be better positioned to protect the rights and interests of relevant parties.

\section{But is there a choice between a political, quasi-judicial or judicial one?}

The dispute resolution mechanism under the WTO comes with judicial characteristics, whereas that of NAFTA has much more to do with politics, under which consultation plays a pivotal role. Taking into consideration the complicated geopolitics of areas covered by the BRI, a dispute resolution mechanism with a high judicial level at an early stage is hard to achieve. Making consultation a pre-condition would not only help maintain a good relationship between the parties, but would provide a window of opportunity for parties to resolve their conflicts and disputes, to the greatest possible extent, through an amicable process. Following these amicable negotiations, the next step would be mediation, mediation. The particular form of the proposed mechanism will need to be hybrid to maintain the flexibility needed. The particular mechanism employed in each case will need to vary, and be regulated to minimize tensions and maximize effectiveness. With discretion, "harmony" and legal creativity. It cannot be rigid, or absolute. Both parties must be able to claim a win within their governments and states.

If the legal system of one party is under-developed, and the political environment unstable, then a mixed dispute resolution mechanism combining consultation and arbitration could potentially work more efficiently. If the party is well equipped with a fully developed legal system, then a more facilitated mechanism might be more welcomed to achieve a fitting solution.

\section{What kind of cases could be brought to the dispute resolution institute?}

In the case of the BRI, a permanent dispute resolution "registry" is recommended to regulate the dispute. It could be a center ("Center") affiliated with the AIIB, just like the ICSID under the World Bank, because the AIIB maintains international standards as a multilateral development bank. However, the Center could also resolve disputes between countries, in addition to a country and a foreign investor. In other words, the Center would be mandated to deal with international commercial, investment and trade disputes.

At its inception and early stages, the panels and appellate body could be set up, while gradually developing a series of targeted tribunals, including: a maritime tribunal, an environment tribunal, an intellectual property rights tribunal and, even a financial tribunal. As for the qualification of each subject, it could be the authorities, funds and businesses or individuals from all the countries along the B\&R. Accordingly, facilitation arrangements could also be considered if only 
one of the parties is from a country that is a member state of the Center.

\section{How best to treat recognition and enforcement arrangement}

During the process of accepting a new member to the Center, relevant parties could be required to acknowledge that any final decision, award or judgment made by the Center shall be recognized as the final decision made by their local judicial platform. Nevertheless, the contracting party could hold reservations with regard to this provision.

\section{Conclusion}

This is not the end. It is not even the beginning of the end. But it is, perhaps, a beginning. Ever since it was put forward for the first time in 2013, the BRI has attracted attention all over the world. What the Initiative would like to achieve is more than a free trade area, but less than a common market. Through providing an open, inclusive and balanced investment and trade cooperation platform, the BRI aims to achieve a community of common destiny. During the construction process, investment, commercial or trade disputes between individuals, undertakings, institutes, authorities and countries cannot be avoided. However, there is no simple dispute resolution mechanism that could efficiently resolve the above-mentioned conflicts. On the basis of existing well-established mechanisms, we argued that a permanent, institutionalized and comprehensive dispute resolution system could be set up, affiliated with the AIIB, well geared to resolve a variety of conflicts. Nevertheless, due to the particular political and social environments in some $\mathrm{B} \& \mathrm{R}$ countries, a flexible method could be turned to. We specifically proposed the establishment of consultation as the pre-condition for initiating a case before the institute. Among the range of possible methods to regulate disputes, mediation was recommended as presenting critical advantages in the context of the BRI and the B\&R countries-with their tremendous diversity, their sensitivities and their peculiar political and legal complexities. When considering that China will remain the driver and engine of the BRI, nothing could contribute more to the traditional perception of Chinese "harmony" than smart, fair and efficient negotiation mechanisms based on a solid mediation platform. This will allow for the efficient resolution of disputes that arise along the belt, and will not jeopardize the long and promising road ahead.

\section{References}

Asian Development Bank (2010). Estimating Demand for Infrastructure in Energy, Transport, Telecommunications, Water and Sanitation in Asia and the Pacific: 2010-2020.

Dahlan, M. R. (Forthcoming). Investor-State Dispute Settlement (ISDS) Reconceptionalized: Regulation of Disputes, Standards, and Mediation. Pepperdine (Forthcoming).

Faculty of Law, Oxford University (2017). One Belt One Road Summit. A Challenge for International Coordination and Cooperation.

Hamermesh, L. A. (2006). The Policy Foundations of Delaware Corporate Law. Columbia Law Review, 106, 1749. 
Han, X. L., \& Zhai, Y. M. (2017). Investor-State Arbitration Mechanism in Sino-Foreign Investment Agreement under the "Belt and Road" Initiative. Chinese Review of International Law, 5, 32.

Huang, J. (2016). Silk Road Economic Belt: Can Old BITs Fulfill China's New Initiative? Journal of World Trade, 50, 746-750.

Huang, Y. (2017). Why China Invests More in Europe than in the US: Political Sensitivities, Security Concerns and Industrial Structure Direct the Flow. Financial Times.

Kratz, A., \& Stanzel, A. (2016). China's Investment in Influence: The Future of 16+1 Cooperation. European Council on Foreign Relations (ECFR).

Lu, Y. (2017). The Establishment of "Belt and Road" International Investment Disputes Settlement Institution. Chinese Review of International Law, 4, 89-96.

Maçães, B. (2016). New Western Frontier, Conquered by China: A 21st Century Silk Road Takes Shape on Kazakh Border, to Russia's Consternation and beyond EU's Imagination. POLITICO.

Onishi, N., \& Moyo, J. (2017). Robert Mugabe Resigns as Zimbabwe's President, Ending 37-Year Rule. The New York Times.

Queen Mary, University of London and White \& Case (2015). 2015 International Arbitration Survey: Improvements and Innovations in International Arbitration (p. 2).

UNCTAD (2017). World Investment Report 2017: Investment and the Digital Economy (p. 115).

Wang, G. G. (2017). The Belt and Road Initiative in Quest for a Dispute Resolution Mechanism. Asia Pacific Law Review, 25, 1. https://doi.org/10.1080/10192557.2017.1321731

Watt, N., Lewis, P., \& Branigan, T. (2015). US Anger at Britain Joining Chinese-Led Investment Bank AIIB. The Guardian.

Winter, T. (2016). One Belt, One Road, One Heritage: Cultural Diplomacy and the Silk Road. The Diplomat.

Zeng, L. L. (2016). Conceptual Analysis of China's Belt and Road Initiative: A Road towards a Regional Community of Common Destiny. Chinese Journal of International Law, 13, 540-541. 